Cagasan, C.U.G., et al., Production and Quality Evaluation of Wine from Jackfruit Co-Products. International Journal of Life Sciences and Biotechnology, 2021. 4(3): p. 340-352.

DOI: $10.38001 / \mathrm{ijl} 1 \mathrm{sb} .827739$

\title{
Production and Quality Evaluation of Wine from Jackfruit Co-Products
}

\author{
Christian Ulysses G. Cagasan ${ }^{1 *(D)}$, Cail Aleksei V. Lingatong1 ${ }^{(i)}$, Kyle Miguel T.

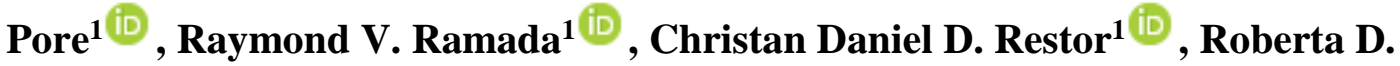 \\ Lauzon $^{1}$ (i)
}

\begin{abstract}
Ripe jackfruit is among the favorite fruits of many people. However, what is usually eaten is the pulp. The other parts, known as co-products like rags, peel, pith, seeds and seed coat are just thrown away as wastes. This study was conducted to find out if jackfruit co-products can be made into a high value product like wine and to determine the physico-chemical and sensory qualities of wine produced from jackfruit co-products. The study had five treatments, with the type of co-products representing the treatments. The wine products from these treatments were evaluated by 10 trained sensory panelists from the Department of Food Science and Technology in the Visayas State University. Results of the study showed that all of the sensory attributes evaluated (i.e., color, taste, aroma, clarity and flavor) did not significantly differ among treatments. After two weeks of fermentation, wine from the five treatments had general mean acceptability ratings ranging from 5.30 (neither like nor dislike) for the wine from jackfruit rags (T3) to 6.2 (like slightly) for the wine from jackfruit peel (T4). In terms of physico-chemical characteristics, the wine from seed coat, pith and peel had acceptable titrable acid (TA) values of $0.53 \%, 0.5 \%$, and $0.44 \%$, respectively. Wine from all treatments also had reduced TSS, which means that sugar was broken down into alcohol, a sign of successful fermentation of the must into wine. These results suggest that the jackfruit co-products are potential raw materials for the processing of wine.
\end{abstract}

\author{
ARTICLE HISTORY \\ Received \\ 19 November 2020 \\ Accepted \\ 11 January 2021
}

\section{KEYWORDS}

Jackfruit wine, sensory evaluation, physicochemical, properties

\section{Introduction}

Jackfruit (Artocarpus heteropyllus Lin) is grown throughout Southeast Asia. Originally a native of India, it is now cultivated in the Philippines. In 1996 to 2008 alone, 200 hectares of large-scale jackfruit planting in the islands of Leyte and Samar was made possible through a government scheme called "plant now, pay later" [1]. The jackfruit is the largest edible tree-grown fruit growing to as much as 35 kilograms in weight [2]. The leaves are a glossy, dark green, and 10 to $15 \mathrm{~cm}$ long. The fruit grows right off the tree trunk and the main branches [3]. One mature jackfruit tree can produce ten to two hundred fruits [4-8]. The individual weight of the fruits varies between 2 and 20

\footnotetext{
1 Visayas State University, Visca, Baybya City, Leyte, Philippines

*Corresponding Autor: Christian Ulysses G. Cagasan, e-mail: chanman.cagasan@gmail.com
} 
kilograms, and even approximately 50 kilograms fruits have been recorded $[7,9,10]$. It is a nutritious fruit, rich in vitamin $\mathrm{C}, \mathrm{B}$-complex group of vitamins and contains very good amounts of vitamin B6 (pyridoxine), niacin, riboflavin, and folic acid [11,3]. The skin of the fruit is more like a shell, with hard, spiny points all over it. The skin is pale green, ripening to a yellowy-brown. When ripe, the fruit will give a little smell when pressed and quite stinky. It does smell better when you get into it, like a combination of banana and pineapple. When ripe, it should sound hollow, like a melon [12].

According to the Agribusiness and Marketing Assistance Division of the Department of Agriculture, jackfruit has many uses [13]. The fruit of jackfruit can be processed into a variety of products. Ripe jackfruit is mostly used for desserts. But what people eat is only the pulp. The pulp only comprise an average of about $30 \%$ of the fruit weight while the other $60 \%$ of the fruit are unutilized waste or co-products [6,14]. The co-products (i.e., peel, rags, pith, seeds and seed coat) are just thrown away, adding to the volume of wastes that we need to manage properly. One of the co-products of jackfruit is called rags, [15]. It is the fibrous materials within the fruit which comprise about $30-50 \%$ of the whole fruit. Few people use the rags for cooking, or as one of the ingredients in fruit salads. Even if the rags are high in pectin, not everyone bothers to do anything with it. Many people are not aware that when pectin which can be derived from the rags are consumed,it bears important positive effects on human health including reducing cancer development [16], lowering blood cholesterol and blood glucose level [17,18], and stimulating the immune response [19]. They make it a habit to throw the jackfruit rags away. In effect, a lot of jackfruit rags have been found in the garbage areas since many people are unaware of the benefits it can bring. Most jackfruit growers and consumers do not know that we can make several products out of the jackfruit rags and consequently turns waste into useful and profitable one. Other wastes or co-products of jackfruit are the peel, pith, seed coat and seeds. Like the rags, these parts of jackfruit are just thrown away because most of the people do not know that these can be processed into valuable products.

With the present economic crisis that we are facing, we do not want to throw leftovers such as the jackfruit co-products. Hence, this study was conducted to explore the feasibility of using jackfruit co-products or wastes (peel, pith, seed coat, rags and over ripe pulps) into high value products such as wine. Aside from the possible additional 
income we can derive from the wine using jackfruit co-products, utilization of jackfruit co-products can also help lessen the wastes in our surroundings and ultimately help in the beautification and care of the environment. Thus this study was conducted to: (1) Find out if jackfruit co-products like rags, peel, pith, seed coat and over ripe pulp could be made into wine; and (2) determine the sensory qualities and physicochemical properties of wine produced from jackfruit co-products.

\section{Material and Methods}

The jackfruit co-products were the main materials for the production of dinner wine. These were taken from the Jackfruit Processing Plant of the Department of Food Science and Technology (DFST) in the Visayas State University (VSU), Visca, Baybay City, Leyte. This study had five treatments. What was varied here was the type of co-products used as the main ingredients in the production of sweet wine. Treatments: T1 - seed coat, T2 - pith, T3 - rags, T4 - peel, and T5 - overripe pulp. The amount of the other ingredients (i.e., water, sugar, lemon juice and wine yeast) used for wine production was held constant, or the same in all treatments.

\section{Product formulation}

The process of producing wine from jackfruit co-products is presented in Figure 1. 


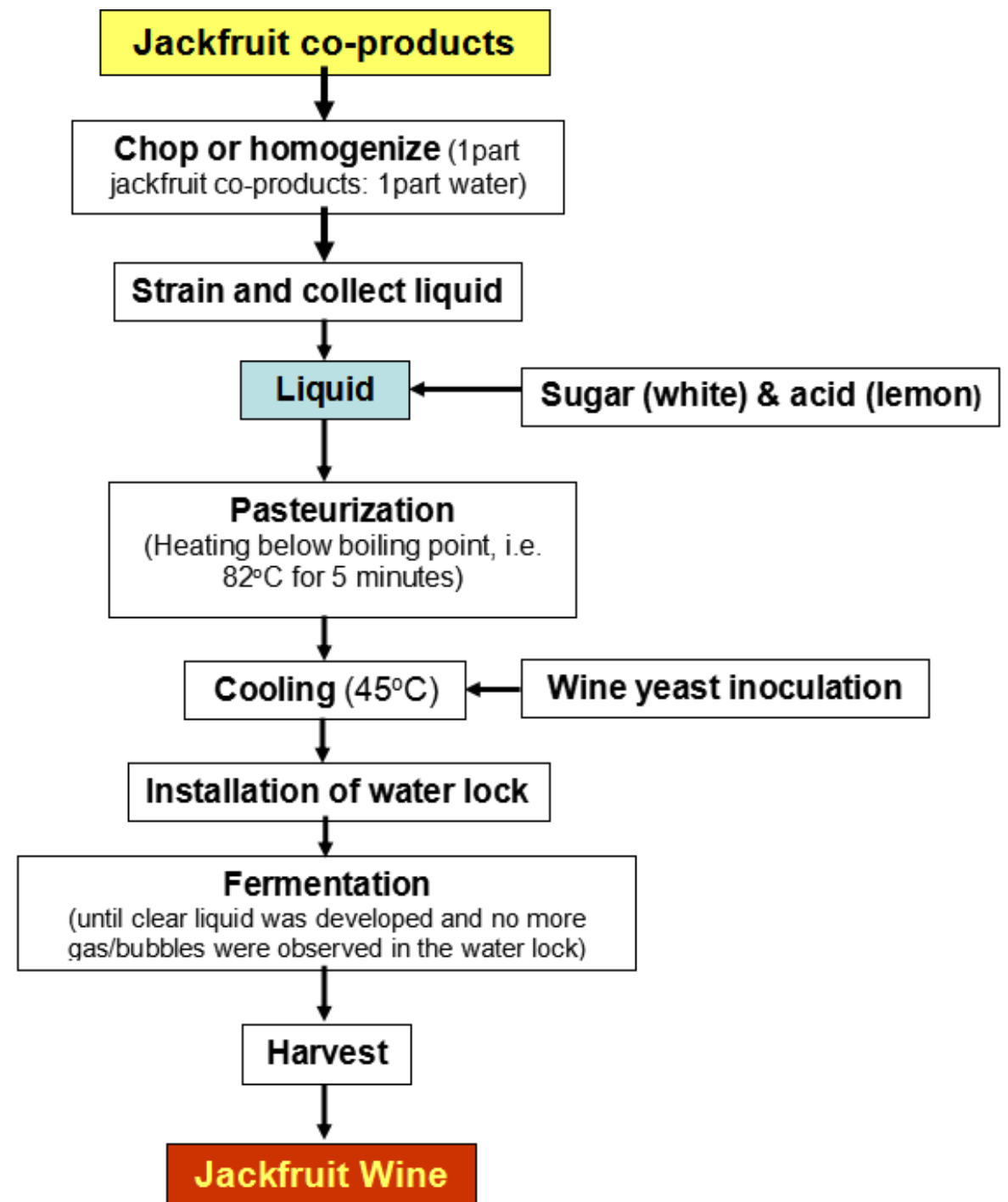

Fig 1 Process flow in producing wine from jackfruit co-products

\section{Product quality evaluation}

The jackfruit wine harvested from the different treatments was subjected to product quality evaluation. The product quality parameters evaluated include sensory quality and physicochemical properties (Fig. 2). The procedures followed in evaluating these parameters are described below. 


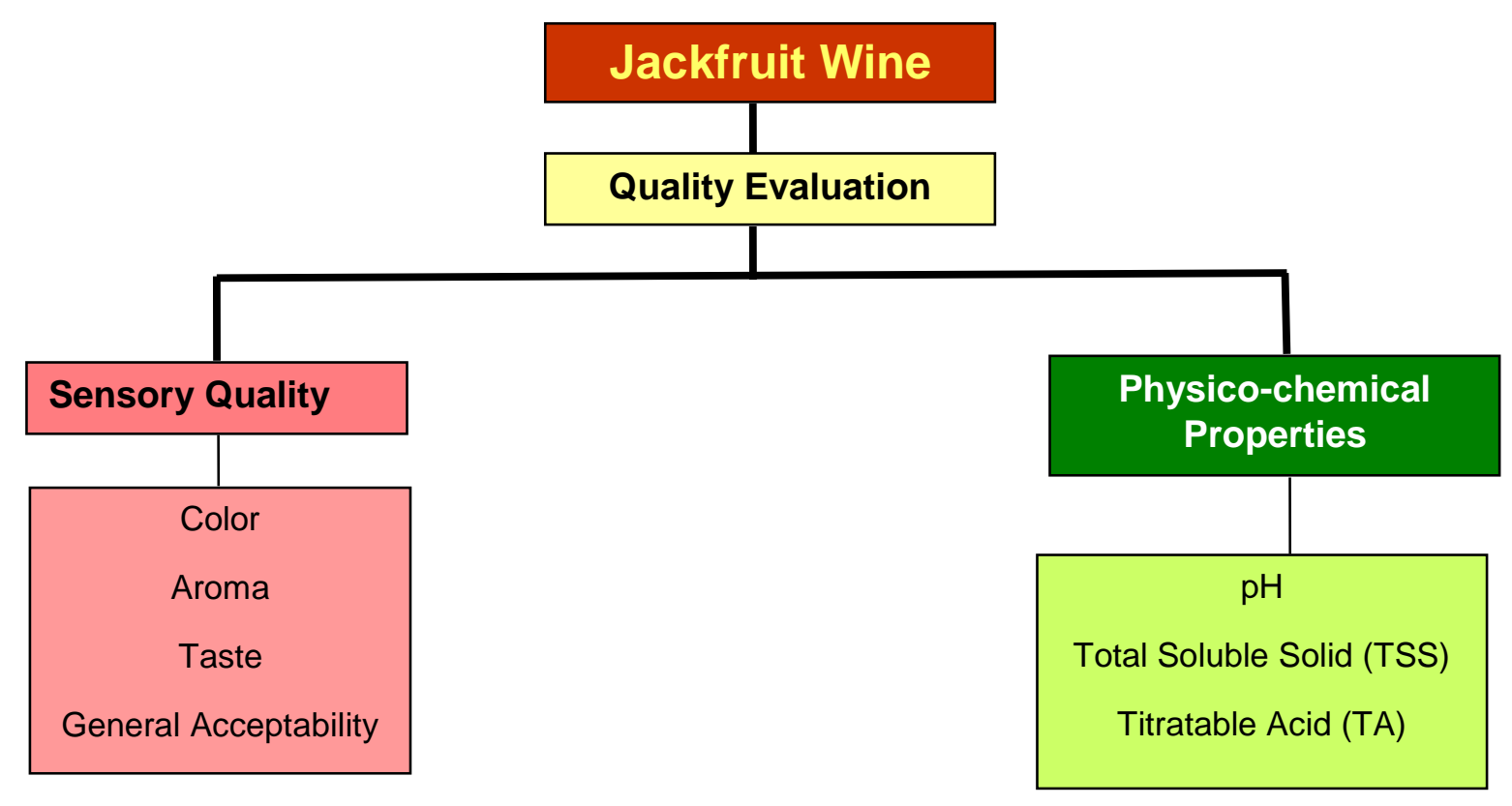

Fig 2 Parameters and attributes considered in the evaluation of the quality of the wine produced from jackfruit co-products

\section{Sensory quality evaluation}

The jackfruit wine representing the five treatments was evaluated by 10 sensory panelists from the Department of Food Science and Technology (DFST). The sensory attributes considered in the evaluation include the color, taste, aroma and general acceptability of the jackfruit wine. Each attribute was rated by the panelists using the nine-point Hedonic Rating Scale as follows: 1- dislike extremely; 2 - dislike very much; 3 - dislike moderately; 4 - dislike slightly; 5 - neither like nor dislike; 6 - like slightly; 7 - like moderately, 8 - like very much, and 9 - like extremely.

Data were analyzed using descriptive statistics, including totals and means. To determine differences among treatments, the Kruskal-Wallis test was used.

\section{Physicochemical properties evaluation}

In addition to evaluating the sensory attributes of the wine from the jackfruit co-products, their physicochemical properties were also determined. The physicochemical properties that were considered in this study include the $\mathrm{pH}$ (to measure the acidity of the wine), total soluble solid (TSS), titratable acid (TA) and alcohol content. Standard procedures used in measuring these properties were followed. 


\section{Results and Discussion}

\section{Sensory quality evaluation}

\section{Quality description}

Results of the quality evaluation of the wine produced from different jackfruit co-products are summarized in Table 1. As perceived by the sensory evaluators, color of the wine from the different jackfruit co-products ranged from brown to yellow. Among the resulting wine, only that from over ripe pulp $\left(\mathrm{T}_{5}\right)$ got a yellow color. This could be because the pulp when compared to its other parts contains higher amount of carotenoids, a class of natural pigments which makes many fruits and some animals have a yellow-reddish color [20]. According to recent studies the key carotenoids found in jackfruit are all-trans-lutein, all-trans- $\beta$-carotene, all-trans-neoxanthin, 9-cis-neoxanthin, and 9-cis-vio-laxanthin [21].

Regarding aroma, all of the wine products had slightly perceptible to moderately perceptible jackfruit aroma. For taste, $\mathrm{T}_{3}$ (wine from rags) was perceived by the sensory panelists to be bitter, while $\mathrm{T}_{1}$ (wine from seed coat), $\mathrm{T}_{2}$ (wine from pith) and $\mathrm{T}_{4}$ (wine from peel) were perceived to have a slightly sour taste. $T_{5}$ (wine from over ripe pulp) was considered by the evaluators to have bitter to slightly sour taste.

In terms of the clarity of the wine, all of the treatments were perceived by the evaluators to have cloudy appearance. This could be because of the short aging period which was not enough to allow the sediments to settle and to make the wine clear. For flavor, $\mathrm{T}_{1}$ (wine from seed coat), $\mathrm{T}_{2}$ (wine from pith), $\mathrm{T}_{3}$ (wine from rags) and $\mathrm{T}_{4}$ (wine from peel) were perceived by the evaluators to have a moderate alcoholic flavor, while $\mathrm{T}_{5}$ (wine from over ripe pulp) was perceived to have a weak alcohol flavor. 
Table 1 Quality description of wine from different jackfruit co-products

\begin{tabular}{llllll}
\hline \hline \multirow{2}{*}{ Treatments } & \multicolumn{5}{c}{ QUALITY DESCRIPTIONS } \\
\cline { 2 - 6 } & Color & Aroma & Taste & Clarity & Flavor \\
\hline $\mathrm{T}_{1}$-Seed coat & Brown & $\begin{array}{l}\text { Slightly } \\
\text { perceptible }\end{array}$ & Slightly sour & $\begin{array}{l}\text { Moderately to } \\
\text { very much } \\
\text { cloudy }\end{array}$ & $\begin{array}{l}\text { Moderately } \\
\text { alcoholic }\end{array}$ \\
$\mathrm{T}_{2}$-Pith & $\begin{array}{l}\text { Brownish } \\
\text { yellow }\end{array}$ & $\begin{array}{l}\text { Slightly } \\
\text { perceptible }\end{array}$ & Slightly sour & $\begin{array}{l}\text { Very much } \\
\text { cloudy }\end{array}$ & $\begin{array}{l}\text { Moderately } \\
\text { alcoholic }\end{array}$ \\
$\mathrm{T}_{3}$-Rags & $\begin{array}{l}\text { Very light } \\
\text { brown }\end{array}$ & $\begin{array}{l}\text { Moderately } \\
\text { perceptible }\end{array}$ & Bitter & $\begin{array}{l}\text { Slightly } \\
\text { cloudy }\end{array}$ & $\begin{array}{l}\text { Moderately } \\
\text { alcoholic }\end{array}$ \\
$\mathrm{T}_{4}$-Peel & $\begin{array}{l}\text { Very light } \\
\text { brown }\end{array}$ & Absent & Slightly sour & $\begin{array}{l}\text { Slightly } \\
\text { cloudy }\end{array}$ & $\begin{array}{l}\text { Moderately } \\
\text { alcoholic }\end{array}$ \\
$\mathrm{T}_{5}$-Over-ripe & Yellow & Absent to & Bitter and \\
Pulp & slightly sour & $\begin{array}{l}\text { Slightly to } \\
\text { moderately } \\
\text { cloudy }\end{array}$ & Weak \\
\hline \hline
\end{tabular}

\section{Sensory acceptability rating}

The acceptability ratings of the wine products in terms of their sensory attributes is presented in Table 2.

\section{Color}

Of the five treatments, $T_{5}$ (wine from over ripe pulp) had the highest mean color acceptability rating of 6.90 , which is equivalent to "like moderately" in the 9 - point hedonic scale. This is possible because of all the co-products used in the study, it is only the pulp that contains beta carotene as exhibited by its dark yellow color [22]. The beta carotene could be the one responsible for the product's yellow color. Results of the Kruskal-Wallis test (Table 3), however, showed that the mean color acceptability ratings of the treatments were not significantly different from each. This means that in terms of color of the resulting wine, over-ripe pulp could not be considered as significantly better than the other jackfruit co-products. 
Table 2 Mean acceptability ratings of wine from different jackfruit co-products

\begin{tabular}{|c|c|c|c|c|c|c|}
\hline \multirow[b]{2}{*}{ Treatments } & \multicolumn{6}{|c|}{ SENSORY ATTRIBUUTES * } \\
\hline & Color & Aroma & Taste & Clarity & Flavor & $\begin{array}{c}\text { General } \\
\text { acceptability }\end{array}$ \\
\hline $\mathrm{T}_{1}$ - Seed coat & 5.50 & 6.40 & 5.40 & 5.90 & 5.90 & 5.90 \\
\hline $\mathrm{T}_{2}$ - Pith & 5.90 & 6.60 & 5.60 & 6.50 & 6.50 & 5.90 \\
\hline $\mathrm{T}_{3}$ - Rags & 6.40 & 7.20 & 5.50 & 6.60 & 5.50 & 5.30 \\
\hline $\mathrm{T}_{4}$ - Peel & 6.30 & 6.40 & 5.60 & 6.50 & 6.50 & 6.20 \\
\hline $\begin{array}{c}\mathrm{T}_{5} \text { - Over-ripe } \\
\text { Pulp }\end{array}$ & 6.90 & 6.90 & 5.00 & 5.70 & 5.60 & 5.60 \\
\hline
\end{tabular}

Table 3 Results of the Kruskal-Wallis test showing differences among treatments in terms of their sensory attributes

\begin{tabular}{lcccc}
\hline Sensory Attributes & Chi-Square & df & Assymp. Sig. & Remarks \\
\hline Color & 6.422 & 4 & 0.170 & $\mathrm{~ns}$ \\
Aroma & 3.886 & 4 & 0.422 & $\mathrm{~ns}$ \\
Taste & 0.474 & 4 & 0.976 & $\mathrm{~ns}$ \\
Clarity & 4.111 & 4 & 0.391 & $\mathrm{~ns}$ \\
Flavor & 2.741 & 4 & 0.602 & $\mathrm{~ns}$ \\
General acceptability & 3.083 & 4 & 0.544 & $\mathrm{~ns}$ \\
\hline \hline
\end{tabular}

ns - not significant

\section{Aroma}

In terms of aroma, the wine from rags $\left(\mathrm{T}_{3}\right)$ had the highest mean acceptability rating of 7.2, which is equivalent to "liked moderately." However, as shown in Table 3, this mean acceptability rating was not significantly different from the mean ratings of the other treatments, which ranged from 6.4 to 6.9 (see Table 2). These ratings show that in terms of aroma, the wine from the other jackfruit co-products were also liked slightly to moderately by the evaluators.

\section{Taste}

As shown in Table 2, wine products from all of the five treatments had considerably low acceptability rating in taste. The sensory panelists' ratings of the products ranged from 5.0 (for $\mathrm{T}_{5}$ ) to 5.60 (for $\mathrm{T}_{2}$ and $\mathrm{T}_{4}$ ), which is equivalent to neither like nor dislike in the Hedonic rating scale. This low acceptability rating in taste may be caused two factors. First, due to time limitation, fermentation and aging time of the wine products were shortened. This could be the reason why the wine products in all treatments were still perceived as sour by the sensory evaluators. Second, the sensory evaluators were 
students of DFST. Even if they were trained sensory panelists, they are not used to drinking wine, so they could have find it difficult to determine what is an acceptable taste of a wine.

\section{Clarity}

Mean acceptability rating of the wine products from the five treatments did not differ significantly as shown in Tables 2 and 3. The ratings ranged from 5.7 (neither like nor dislike) for the wine from over ripe pulp $\left(\mathrm{T}_{5}\right)$ to 6.6 (like moderately) for $\mathrm{T}_{3}$ (wine from rags) (Table 2).

\section{Flavor}

Wine from different jackfruit co-products exhibited alcoholic flavor that did not significantly differ from each other (Table 3). As shown in Table 2, the mean acceptability ratings for flavor ranged between 5.50 (neither like nor dislike) for the wine from rags $\left(\mathrm{T}_{3}\right)$ to 6.50 (like slightly) for $\mathrm{T}_{2}$ (wine from pith) and $\mathrm{T}_{4}$ (wine from peel).

\section{General acceptability}

Among the treatments, $\mathrm{T}_{4}$ (wine from peel) got the highest mean acceptability rating of 6.20 , equivalent to like slightly. The other treatments $\left(\mathrm{T}_{1}, \mathrm{~T}_{2}, \mathrm{~T}_{3}\right.$ and $\left.\mathrm{T}_{5}\right)$ got a general mean acceptability rating that ranged between 5.30 to 5.90, which fall under the "neither like nor dislike" to "like slightly" categories of the Hedonic rating scale. Result of the Kruskal-Wallis test (Table 3), however, showed that the mean general acceptability ratings of the wine from the different jackfruit co-products did not differ significantly from each other. Based on the results of the sensory evaluation, jackfruit co-products are potential materials for wine making since the resulting wine were already liked even slightly by the sensory evaluators even if the fermentation and aging time were only short due to time limitation.

\section{Physicochemical properties evaluation}

\section{Total soluble solids}

Total soluble solids (TSS) measures the percent sugar as well as other dissolved solids in solutions. It is measured using the Brix scale or degrees Brix. In producing certain alcoholic beverages, the sugar concentration of the initial solution often affects the alcohol content after the fermentation process [23]. 
In this study, it was observed that the TSS values of all treatments decreased (Table 4). All treatments had initial TSS values of 14, but after two weeks of fermentation the resulting TSS values ranged only from 4.3 to 6.0 .

Table 4 Physicochemical properties of the wine from jackfruit co-products

\begin{tabular}{lcccc}
\hline \multirow{2}{*}{ Treatments } & \multicolumn{2}{c}{ Total Soluble Solids (TSS) } & \multirow{2}{*}{\begin{tabular}{c} 
pH of the \\
must \\
\cline { 2 - 3 } (Initial)
\end{tabular}} & $\begin{array}{c}\text { Titrable Acid } \\
\text { (TA) } \\
\text { (Final) }\end{array}$ \\
\hline & Initial & Final & & \\
$\mathrm{T}_{1}$ - Seed coat & 14 & 6.0 & 4 & $0.53 \%$ \\
$\mathrm{~T}_{2}$ - Pith & 14 & 4.9 & 4 & $0.50 \%$ \\
$\mathrm{~T}_{3}$ - Rags & 14 & 4.9 & 4 & $0.13 \%$ \\
$\mathrm{~T}_{4}$ - Peel & 14 & 5.1 & 5 & $0.44 \%$ \\
$\mathrm{~T}_{5}$ - Over-ripe Pulp & 14 & 4.3 & 5 & $0.08 \%$ \\
\hline \hline
\end{tabular}

This means that the fermentation was successful because the microorganisms in the fermented solution were able to degrade the sugar and convert it into alcohol, which is the desired outcome in wine making.

$p H$

The $\mathrm{pH}$ value measures the acidity of the wine. Solutions with a $\mathrm{pH}$ below 7 are acidic whereas solutions with a $\mathrm{pH}$ above 7 are alkaline. In wine tasting, excessive acidity leads to a sourness perception while low acidity decreases the flavor harmony [24]. In this study, only the $\mathrm{pH}$ values of the must (liquid for fermentation) of all treatments were determined. The $\mathrm{pH}$ values of the treatments after two weeks of fermentation were not determined because the $\mathrm{pH}$ meter was out of order. As shown in Table 4, all treatments had $\mathrm{pH}$ values below 7 indicating that the solutions were acidic. The researchers, however, could not determine if there was increase in the level of wine acidity after the fermentation process using $\mathrm{pH}$ value as the determinant [25].

\section{Titratable acid}

Wines contain organic acids which come from its fruit source. However, many other acids are formed during and after the alcoholic fermentation [26]. To determine the quantity of titratable acid (TA) in the wines produced from jackfruit co-products, a procedure known as acid-base titration was performed. In the wine making industry, the regulations dictate the minimum acid levels of 0.5 percent in table wines if the must or wine is ameliorated. Most of the commercially produced wines contain acid levels in the 
range of 0.6 to 0.9 percent [27]. In this study, results showed that wines from seed coat $\left(\mathrm{T}_{1}\right)$ and pith $\left(\mathrm{T}_{2}\right)$ had acceptable titratable acid values of $0.53 \%$ and $0.50 \%$, respectively. Wine from the peel $\left(\mathrm{T}_{4}\right)$ even had a TA value of $0.44 \%$, which is already near the minimum acceptable level. These results suggest that the seed coat, pith and peel of jackfruit are potential materials in the production of wine [28].

\section{Conclusion}

Based on the results of the study, it can be concluded that:

1. The jackfruit co-products are potential materials that can be processed into wine because even only after two weeks of fermentation, the wine products already got mean general acceptability ratings above 5.0.

2. The sensory qualities of the jackfruit wine were not influenced by the type of co-products used for the processing of wine. Thus, any of the jackfruit co-products are potential materials for the processing of wine.

3. Wine from jackfruit co-products had acceptability ratings between 5.0 (neither like nor dislike) to 6.2 (like slightly), which indicates that there is still a need to improve the process of wine production to improve its acceptability.

\section{Recommendation}

This study focused on the production and quality evaluation of wine from jackfruit co-products (seed coat, pith, rags, peel, and over ripe pulp), which are not the usual materials used in producing wine. This suggests that there is still a need to study further the following aspects to improve the quality of the wine from jackfruit co-products:

1. Duration of the fermentation and aging process;

2. Production of wine from a mixture of jackfruit co-products;

3. Evaluation of the wine's sensory qualities by experts in wine tasting.

\section{Acknowledgements}

We sincerely thank the faculty and staff of the Department of Food Science and Techonolgy, Visayas State University for their assistance and support in this study.

\section{Funding}

This study is not funded by any organization.

\section{Availability of data and material}

Please contact the corresponding author for any data request. 


\section{References}

1. Borines, L. M., et al., Jackfruit decline caused by Phytophthora palmivora (Butler). Australasian Plant Pathology, 2013. 43 (2): p. 123-129.

2. Prakash, O., et al., Artocarpus heterophyllus (Jackfruit): An Overview. Phcog Rev, 2009. 3 (6): p. 353-358

3. Mushumbusi, D. G., Production and Characterization of Jackfruit Jam. [Master of Science in Food Science Thesis], Sokoine University of Agriculture, Morogoro, Tanzania, 2015.

4. Alagiapillai, O. A., et al., "PPI-I jack: A new high yielding, regular bearing jack variety for Tamil Nadu," Madras Agricultural Journal, 1996. 83: p. 310-312.

5. Haq, N., "Jackfruit (Artocarpus heterophyllus)," Tropical Fruit Trees. 2006, Southampton Centre for Underutilised Crops, University of Southampton, Southampton, UK.

6. Narasimham, P., "Breadfruit and jackfruit," Fruits of Tropical and Subtropical Origin: Composition. Properties and Uses. 1990, Florida Science Source, Lake Alfred, Florida, USA.

7. Reddy, B. M. C., et al., "Studies on physic-chemical characteristics of jackfruit clones of south Karnataka, Karnataka,” Journal of Agricultural Science, 2004. 17 (4): p. 279-282.

8. Sammadar, H. M., "Jackfruit," Fruits of India: Tropical and Subtropical. 1985, Naya Prokash, Calcutta, India.

9. Mitra, S. and Mani, D., "Conservation and utilisation of genetic resources in jackfruit (artocarpus heterophyllus lamk.) - a potential underutilised fruit," Acta Horticulturae, 2000. 523: p. 229-232.

10. Selveraj, Y. and Pal, D. K., "Biochemical changes during ripening of jackfruit (Artocarpus heterophylllus Lam," Journal of Food Science and Technology, 1989. 26: p. 304-307.

11. Swami, S. B., et al., "Jackfruit and its many functional components as related to human health: a review," Comprehensive Reviews in Food Science and Food Safety, 2012.11 (6): p. 565-576.

12. Morton, J., Jackfruit, Fruits of Warm Climates. 1987, Miami, FL.

13. Department of Agriculture, Jackfruit: A Commodity Profile, 2010. Tacloban City, Philippines: Agribusiness and Marketing Assistance Division, Department of Agriculture.

14. Subburamu, K., et al., A Study on the Utilization of Jack Fruit Waste. Short communication. Bioresource Technology, 1992. 40: p. 85-86.

15. Mortensen, E. L.,et al., Better psychological functioning and higher social status may largely explain the apparent health benefits of wine: a study of wine and beer drinking in young Danish adults. Arch Intern Med, 2001. 161: p. 1844-1848

16. Jackson, C.L., et al., Pectin Induces Apoptosis in Human Prostate Cancer Cells: Correlation of Apoptotic Function with Pectin Structure. Glycobiology, 2007. 17: p. 805-819.

17. Behall, K., and Reiser, S., Effects of Pectin on Human Metabolism, in "Chemistry and Functions of Pectins", American Chemical Society, 1986. p. 248-265.

18. Brown, L., et al., Cholesterol Lowering Effects of Dietary Fiber: A Meta-Analysis. The American Journal of Clinical Nutrition, 1999. 69: p. 30-42.

19. Inngjerdingen, K. T., et al., Immunological and Structural Properties of a Pectic Polymer from GlinusOppositifolius. Glycobiology, 2007. 17: p. 1299-1310.

20. De Faria, A. F., de Rosso, V. V., and Mercadante, A. Z., Carotenoid Composition of Jackfruit (Artocarpus heterophyllus), Determined by HPLC-PDA-MS/MS. Plant Foods for Human Nutrition, 2009. 64 (2): p. 108-115.

21. Baliga, M. S., et al., "Phytochemistry, nutritional and pharmacological properties of Artocarpus heterophyllus Lam. (jackfruit): A review," Food Research International, 2011. 44 (9): p. 18001811.

22. Chandrika, U. G., Jansz, E. R., and N. D. Warnasuriya, "Analysis of carotenoids in ripe jackfruit (Artocarpus heterophyllus) kernel and study of their bioconversion in rats," Journal of the Science of Food and Agriculture, 2004. 85 (2): p. 186-190. 
23. Ball, D. W., Concentration Scales for Sugar Solutions. Journal of Chemical Education, 2006. 83(10), p. 1489.

24. Moreno-Arribas, M. V. M. and Polo, M. C., Wine Chemistry and Biochemistry. Springer Science and Business Media, 2008.

25. Kumoro, A. C., et al., Preparation of Wine from Jackfruit (Artocarpus heterophyllus lam) Juice Using Baker yeast: Effect of Yeast and Initial Sugar Concentrations. World Applied Sciences Journal, 2012. 16: p. 1262-1268.

26. Nielsen, S., Food Analysis. Springer Science and Business Media, 2003.

27. Amerine, M. A. and C. S. Ough., Methods for analysis of musts and wines. John Wiley and Sons, New York, 1980.

28. Bhavya, H. T., Transformation of polyphenols in fruits during fermentation: Wine from passion fruit (Passiflora edulis). 2009, CFTRI, Mysore, India. 